\title{
Marine carotenoids: recent progress
}

\author{
Synnøve Liaaen-Jensen \\ Organic Chemistry Laboratories, Norwegian Institute of Technology \\ University of Trondheim-NTH, N-7034 Trondheim, Norway
}

\begin{abstract}
Progress on marine carotenoids over the past three years is reviewed. Structural elucidation including stereochemical assignments, improved methodology for such studies and partial syntheses are treated. Unpublished results from the author's laboratory are included. Several applied aspects are mentioned.
\end{abstract}

\section{INTRODUCTION}

This review covers work on the chemistry of marine carotenoids published during the past three years. The available literature is treated in a selective and critical manner from a natural product chemist's point of view. Unpublished results from the author's laboratory are also included.

The title subject was discussed in papers on carotenoids of lower plants by Bjornland (ref. 1) and on carotenoids in animals by Matsuno (ref. 2) in the 8 th International Carotenoid symposium. Since then reviews have appeared on marine carotenoids by Matsuno and Hirao (ref. 4) and on carotenoids and polyterpenoids by Britton (ref. 3), both covering literature prior to 1988, and on algal carotenoids (ref. 5), carotenoids of Chromophyta (ref. 6), allenic and acetylenic carotenoids (ref, 7) and selected topics on marine carotenoids (ref. 8) from our laboratory.

Amongst the around 600 naturally occurring carotenoids which are structurally defined (ref. $9)$ the largest structural variety is encountered in marine carotenoids. Acetylenic carotenoids appear to be restricted to aquatic, including marine, environments.

De novo synthesis of carotenoids in the ocean is mainly carried out by microscopic and macroscopic algae, and to a much lesser extent by photosynthetic and non-photosynthetic bacteria. Structural modifications are effected by various marine animals along the food chain.

This review will treat progress in the chemistry of marine carotenoids from bacteria, algae and animals separately; otherwise a structural approach is used.

It has been postulated that NaCl-requiring microorganisms isolated from fresh water should also be encountered in the marine environment. In fact the question has been raised if the existence of purely marine bacteria is a myth or a reality (ref. 10). No clear differentiation is therefore attempted in this review between marine bacteria or microalgae and those from fresh water.

\section{BACTERIA}

The aerobic phototrophic bacterium Erythrobacter longus has an unusual carotenoid composition (ref. 11). A new cross-conjugated carotenal has been assigned the structure (3R) -9'-cis-1'-methoxy-3',4'-didehydro-1',2-dihydro- $\beta, \psi$-caroten-3-ol (1, Scheme 1 ) on the basis of spectroscopic data (ref. 12). The 3-OH-B-ring is rare and the 19-al structural feature new in the context of phototrophic bacteria. Detailed ${ }^{1} \mathrm{H}$ NMR analyses of the synthetic 13-cis-renierapurpurin-20-al ()ㅡ, its 7,13-di-cis, 13,7'-dicis and 13,9'-dicis (ref. 13) and 9,13'-dicis and 13,13'-dicis (ref. 14) isomers have since been reported as models for cross-conjugated carotenals.

A chemosystematic comparison of mycobacterial species on the basis of their carotenoid content has been reported (ref, 15). B,B-Carotene was the common pigment together with partly characterized zeaxanthin-like and eschscholtzxanthin-like hypophasic carotenoids.

Carotenes of the genus Rhodococcus (ref, 16) and carotenoids of the cyanobacterium Aphanothece SD. isolated from a salt marsh (ref. 17) have been studied. Profiling and quantitation of bacterial carotenoids by HPLC are convenient (ref, 18). 
Glycosidic carotenoids are common in bacteria such as flexibacteria and cyanobacteria (blue-green algae). Improved methodology, including complete assignment of high-field ${ }_{\mathrm{H}}$ NMR spectra of the free and acetylated glycosides and $G C$ analysis of silylated methyl glycosides derived from the carotenoid glycosides, has now revealed that different sugars may be glycosidically bound to the same aglycone in a given source (refs. 19-21). Thus sarcinaxanthin (3) ex sarcina lutea (now Micrococcus luteus) has been shown to occur both as a glucoside and a mannoside (ref. 21) and myxol (4) and oscillol (4b) to occur both as $\alpha$-chivonoside and $\alpha$-fucoside in the same cyanobacteria (refs. 21,22 ).

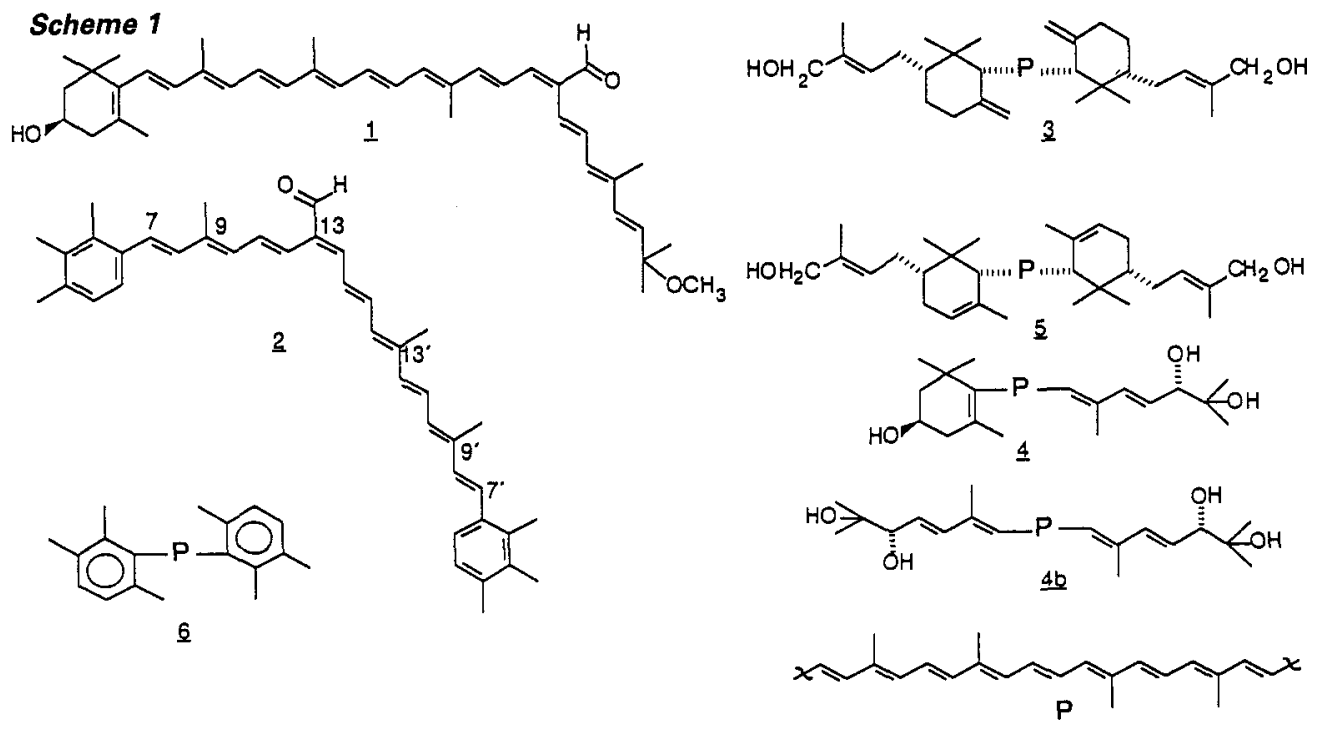

Activity towards the total syntheses of $C_{45}$ and $C_{50}$ bacterial carotenoids has been continual, and details on the synthesis of optically active $\left(2 \underline{R}, 6 \underline{R}, 2^{\prime} \underline{R}, 6^{\prime} \underline{R}\right)$-decaprenoxanthin ( $\underline{5})$ (ref. 23) and of ( \pm )-all-E-sarcinaxanthin ( $\underline{3}$ ) (ref. 24) have been published.

Isorenieratene (6) derived from bacteria or sponge has been considered the likely precursor of several $c_{13}-c_{31}$ aryl isoprenoids in sediments (ref. 25).

\section{ALGAE}

\section{Chemosystematic overviews}

Chemosystematic studies on the carotenoids of several algal classes and on some problematical species have been pursued. Besides an updated review on Chromophyta (ref. 6), two compilations have been published on Bacillariophyceae (diatoms) (refs. 26,27) and three studies on phaeophyceae (brown algae) (refs. 28-30). Work on the carotenoids of Prochloron (Prochlorophyta) (ref. 31), microflagellates (refs, 32,33) dinoflagellates (refs. 34-38), including chrysochromulina polylepis (refs. 36,37) which caused severe killing of fish in Norwegian waters, euglenoids (refs, 39,40), prymnesiophytes (refs. 41,42), a marine chrysophyte (ref, 43) and a raphidophyte (ref. 44) has been performed.

The results further demonstrate the usefulness of carotenoids as chemosystematic markers in algae.

\section{Allenic carotenoids}

Further interest has again been centered around the two major allenic carotenoids fucoxanthin (7a, scheme 2$)$ and the $\mathrm{C}_{37}$-skeletal peridinin ( 8 ). The detailed characterization of 19'-butanoyloxyfucoxanthin ( $7 \mathrm{~b})$ from Pelagococcus subviridis has now been published (ref. 43). Chromatographic separation of fucoxanthin (7a) and its naturally occurring 19'-butanoyloxy (b) and 19'-hexanoyloxy (ㄷ) derivatives by TLC and HPLC are reported (refs. $41,43,45$ ).

An improved isolation procedure for larger scale isolation of fucoxanthin (7a) based on liquid-liquid partition has been reported (ref. 46) and has also been employed for the isolation of peridinin ( ) (ref. 47).

Complete ${ }^{1} \mathrm{H}$ NMR and ${ }^{13} \mathrm{C}$ NMR assignments for all-trans and 91 -cis-19'-butanoyloxyfucoxanthin (7b) and all-trans fucoxanthin (7a) have been achieved (ref. 48). Furthermore all stereoisomers present in the iodine-catalyzed stereomutation mixture of fucoxanthin have been identified by high-field ${ }^{1} \mathrm{H}$ NMR as 13-cis, 15-cis (?), 13'-cis, 9'-cis, 13,9'-dicis, 13,13'-dicis and $91,13^{\prime}$-dicis after preparative HPLC separation (ref. 49). The 91,13'dicis and 13,13'-dicis isomers were analyzed as a mixture. 
Scheme 2

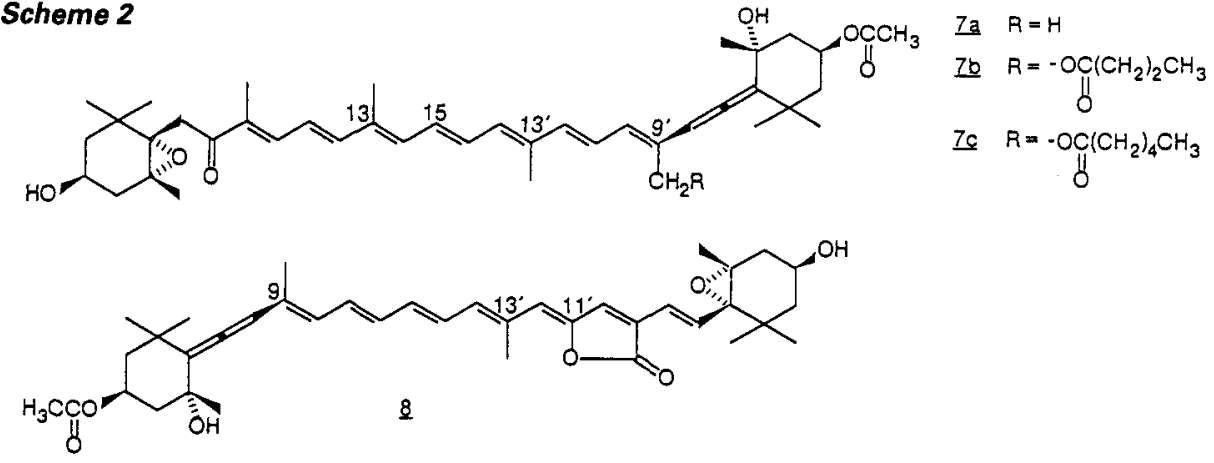

The formation of the allenic (6' $\underline{S})$ isomer of fucoxanthin ( $\left.7 \mathrm{a}, 3 \underline{\underline{S}}, 5 \underline{\underline{R}}, 6 \underline{\mathrm{S}}, 5^{\prime} \underline{\mathrm{R}}, 6^{\prime} \underline{\mathrm{R}}\right)$ upon iodine catalyzed stereomutation had previously been claimed (ref. 50), but was subsequently questioned (ref. 51). This identification has now been disproved, first by the published

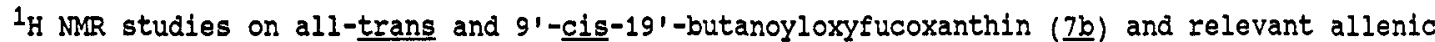
models (refs. 48,52). The 19l-butanoyloxy substituent favours cis isomerization of the adjacent $\Delta 91$ bond. The final, direct proof for fucoxanthin $\left(\frac{7 a}{7}\right)$ itself has now been presented (ref. 49). The results demonstrate that the 9 -cis isomer with 0.5 ppm downfield shift for the allenic proton had been misidentified as the allenic (6' $\underline{S}$ ) isomer.

Interestingly the weak CD spectra of all-trans fucoxanthin (7a) and its 19'-butanoyloxycounterpart ( $7 b)$ are inverted for the 9 '-monocis isomers (refs. 48,49), a characteristic feature associated with conservative $C D$ spectra (ref. 53). The resonance Raman spectrum of fucoxanthin (7a) is now available (ref. 54).

Turning now to the chemistry of fucoxanthin ( $7 a$ ), its alkali lability has intrigued us for a long time and may now be rationalized (ref. 55). Since allenic carotenoids are alkali stable the alkali sensitivity was associated with the keto-epoxy moiety. However, it was not known if the chromophoric changes were caused by a reaction where the base reacted as a base or as a nucleophile. Experiments (ref. 55) with fucoxanthin (7a) and protected fucoxanthin (7d), scheme 3 , have revealed that a $c-7$ hydrogen is readily removed by base and nucleophilic attack of the keto function results in cyclization to a hemiketal $\underline{9}$ with an octaene chromophore, or to a ketal 10 in the presence of a suitable electrophile such as methyl iodide. Isofucoxanthin (11a) and isofucoxanthinol (11b) were isolated as intermediates upon treatment of fucoxanthin (7a), with $5 \% \mathrm{KOH}$ in methanol. This represents the best known procedure for the preparation of the isofucoxanthins. Detailed ${ }^{1} \mathrm{H}$ NMR analysis, including NOE-experiments have demonstrated the configuration of the cross-conjugated keto system shown for $11 a, b$ (ref. 55).

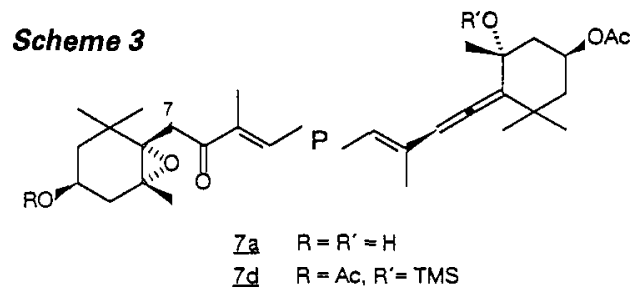<smiles>CC(=CP)C(=O)C=C1C(C)(C)C[C@@H](O)C[C@]1(C)O</smiles>

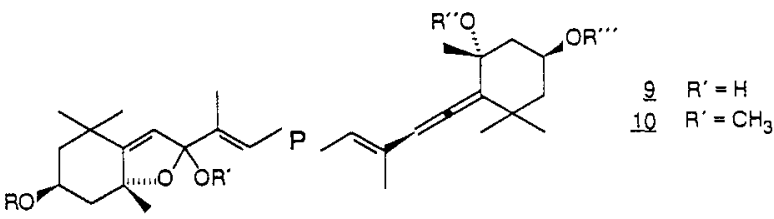<smiles>[X]C=CC(C)=CC=CC=C(C)C=C</smiles>

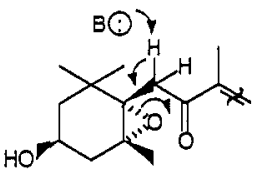

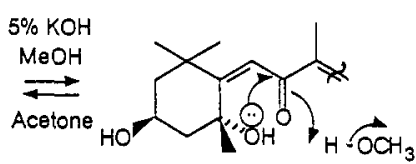<smiles>CC(C)C1(O)C=C2C(C)(C)C[C@@H](O)C[C@]2(C)O1</smiles>

The hemiketals $\underline{g}$ and ketals 10 exhibited extreme sensitivity to acid and were readily converted into blue products identified as oxonium ions of type 12 (ref. 56 ), Scheme 4 . These were reverted to the hemiketal 9 upon treatment with base. Coloured oxonium ions are known in other classes of compounds such as oxacine and xanthene dyes, $\underline{e} . \underline{q} . \underline{13}, \underline{14}$, but have previously not been characterized in the carotenoid field. Such blue carotenoids will be considered again later. 
So-called 5'-dehydrates of fucoxanthin (7a) and fucoxanthinol have been prepared for comparison with sediment constituents (ref. 57), and the fate of fucoxanthin (7a) and other carotenolds in anoxic marine sediments has been discussed (ref. 58). The hemiketals $\underline{9}$ and ketals 10 described above, scheme 3, are relevant in this context.

\section{Scheme 4}<smiles>CC(C)=CC=CC(C)=CC=CC(C)=CC=CC(C)=CC=CC(=O)O</smiles><smiles></smiles><smiles></smiles>

Turning now to peridinin $(\underline{8}$, scheme 2$)$, the ${ }^{13} \mathrm{C}$ MMR spectrum has now been fully assigned (ref. 38) by techniques already employed for $P 457$ (ref. 19), including inverse hetero-cosy and DEPT techniques. Complete $1_{\mathrm{H}} \mathrm{NMR}$ assignments in both $\mathrm{CDCl}_{3}$ (ref. 59) and $\mathrm{CD}_{3} \mathrm{OD}$ ( $\mathrm{ref}$. 47) are now available for the all-trans isomer. Further assignments of the 9-monocis, previously mistaken for the (6s)-isomer, the 13'-monocis and 11',13'-dicis-isomers are in progress (ref. 59). The total synthesis of optically inactive peridinin by Ito and co-workers (ref. 60) is a major contribution discussed elsewhere (ref. 61).

The allenic neoxanthin ( 15 , scheme 5 ) has been shown to be naturally occurring in many sources as g'-cis, by use of careful isolation procedures (ref. 62).

\section{Scheme 5}

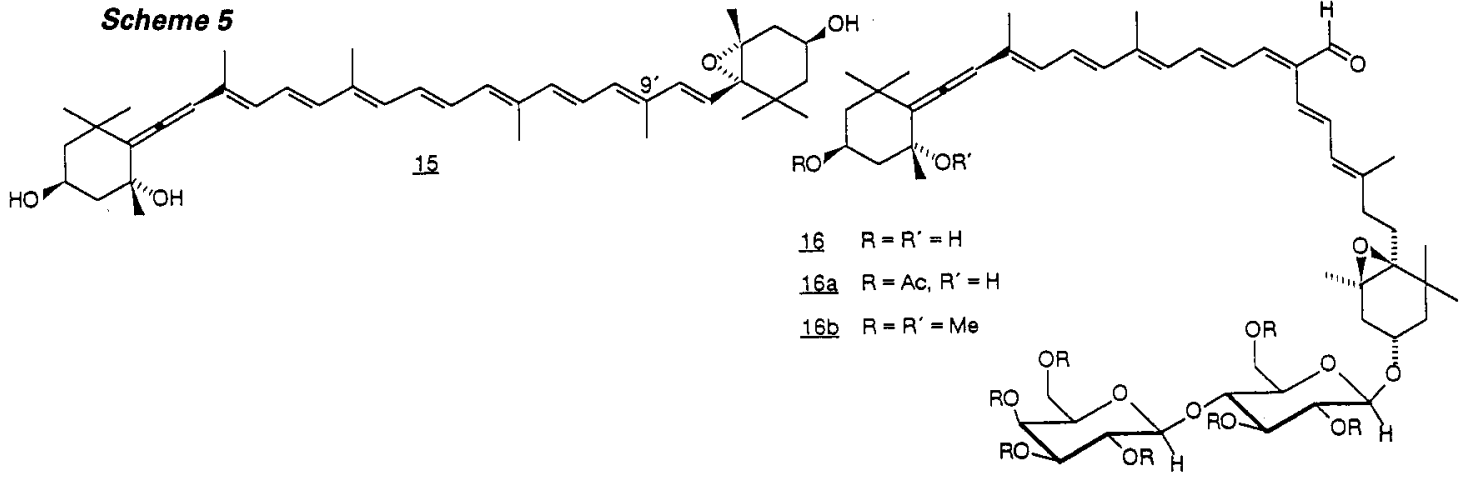

The minor carotenoid glycoside $\mathrm{P} 457$, present in peridinin-producing dinoflagellates, has proved to be a complex neoxanthin derivative, namely 13'-cis-7',8'-dihydroneoxanthin20'-al 3'-B-lactoside (16) (refs. 19,20). By an improved isolation procedure, including removal of water-soluble impurities by liquid-liquid partition, TLC and HPLC, $5 \mathrm{mg}$ of P457 was obtained from $120 \mathrm{l}$ of algal culture. Spectroscopic analyses (VIS, ${ }_{\mathrm{H}}$ and ${ }^{13} \mathrm{C}-\mathrm{NMR}$, including COSY, TOCSY, hetero-COSY, ROESY and DEPT techniques, MS and CD) were effected for P457 (16) itself and its octaacetate (16a) and resulted in MMR-assignment of each proton and carbon in 16 and $16 \mathrm{a}$. (refs. 19,20). The nonamethyl ether (16b), obtained by methylation with $\mathrm{CH}_{3} \mathrm{I} / \mathrm{NaH}$, provided useful MS information and the FAB spectrum of the octaacetate (16a) showed $M=1276$. Acid-catalyzed methanolysis confirmed the presence of glucose and mannose in a 1:1 ratio. The chirality of the allenic end group is compatible with $1_{H}$ NMR and CD data, whereas the absolute configuration of the epoxidic end group is assumed from blogenetic reasoning. Although $\mathrm{C}_{40}$-skeletal, $\mathrm{P} 457$ (16) is structurally one of the most complex carotenoids known to date. In particular the saturated $c-7 \cdot-c-8)^{\prime}$ bond complicated the structural analysis.<smiles>[Y]C(C)(C)C1C[C@@H](O)CC(C)=C1C#C/C(C)=C/C=C/C(C)=C/C=C/C=C(C)/C=C/C=C(C)/C=C/C1=C(C)C(=O)[C@@H](O)CC1(C)C</smiles><smiles>CC1=C(PC2=C(P)CC(C)(C)C2)C(C)(C)CC(O)C1</smiles><smiles>CC1=C(PC2=C(C)C[C@@H](O)CC2(C)C)C(C)(C)CC=C1</smiles><smiles>C#CC(C)=CC=CC(C)=CC=CC=C(C)C=CC=C(C)C#CC</smiles> 
Acetylenic carotenoids

The detailed structural elucidation of the allenic, acetylenic gyroxanthin (17, Scheme 6) (refs. 1,5,34) from dinoflagellates has not yet been published (ref. 63). By FT-IR, a weak acetylenic absorption at $2200 \mathrm{~cm}^{-1}(\mathrm{KBr})$ is consistent with the structure assigned (ref. 64). Details on alloxanthin diester $18 \mathrm{a}$ and pectenolone (19) from Euglena gracilis are pending (ref. 39), whereas the full paper on acetylenic carotenoids from Euglena viridis has appeared (ref. 40). Included are the diacetylenic carotene $\underline{20}$ and esterified carotenol $\underline{21}$.

The $\mathrm{C}_{37}$-skeletal acetylenic carotenoid pyrrhoxanthin (22) from dinoflagellates has now been prepared in the optically inactive form by total synthesis via an acetylenic sulphone:(ref. 60), as discussed elsewhere (ref. 61).

\section{Epoxides}

Epoxides are common amongst algal carotenoids, 5,6-Epoxides of the violaxanthin (23, Scheme 7) type are abundant. By means of the sharpless-Katsuki oxidation naturally occurring violaxanthin $\left(23 ; 3 S, 5 R, 6 S, 3^{\prime} S, 5 \prime R, 6 ' S\right.$, all E) has been prepared by total synthesis by Eugster's group (ref. 65) as treated elsewhere (ref. 66). Complete spectroscopic characterization of violaxanthin $\left(\frac{23}{6}\right)$, including $1_{H} \mathrm{NMR}$ assignments is thereby available (ref. 65). A re-examination of the classical epoxidation of zeaxanthin (24) as diacetate followed by HPLC analysis provided no detectable $\underline{23}$ (ref. 65).<smiles>CC=CC1=C(C)C[C@@H](O)CC1(C)C</smiles>

5,6-Epoxy-5,6-dihydro- $\beta, B$-carotene is the likely precursor of the 5,8-epoxide flavacin, of unknown chirality, that is encountered as a minor carotenoid in blue-green algae (cyanobacteria). For comparison the $C D$ spectra of the synthetic $\left(5 \underline{R}, 6 \underline{S}, 5^{\prime} \underline{R}, 6^{\prime} \underline{S}\right.$ ) diepoxide (ref. 67) and the natural enantiomer (25, ref. 68) from sweet potatoes are now available.

The blue colour obtained by treatment of epoxidic carotenoids with mineral acid has long been a classical colour test. This reaction has now been pursued in our laboratory (ref. 56) for fucoxanthin (7a, Schemes 2,3), violaxanthin (23, Scheme 7) and neoxanthin (15, Scheme 5), and the blue products have been identified as oxonium ions. The results are rationalized in scheme 8 , where the conjugated 5,6-epoxide is readily isomerized to furanoxides in the presence of weak acid. Strong acidic conditions are required for expelling hydride as a leaving group in the subsequent formation of the blue oxonium ions. The latter are converted into yellow hemiketals upon treatment with $\mathrm{kOH}$. Violaxanthin (23) provided a dioxonium ion (26) and neoxanthin (15) and fucoxanthin (7a) mono-oxonium ions with modified allenic end groups $(\underline{26 b})$. The blue products obtained by treatment of epoxidic carotenoids with $\mathrm{HgCl}$ and considered as mercury complexes (ref. 69) may now be identified as oxonium ions. These synthetic blue oxonium salts represent a novel class of blue carotenoids. Previously carotenoproteins and only a few neutral carotenoids with long polyenone chromophores were known.

Scheme 8

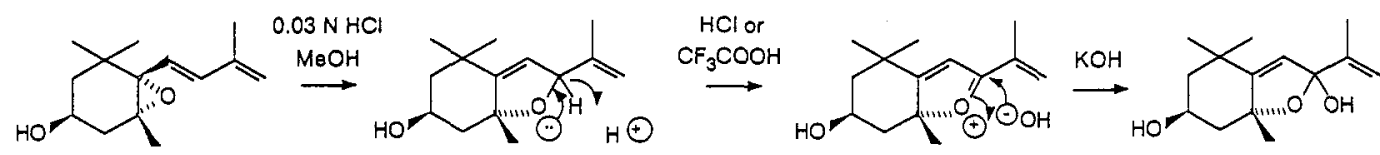

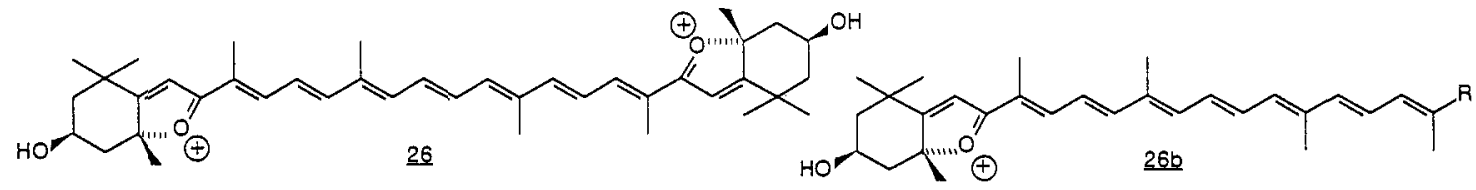

\section{MARINE ANIMALS}

Since animals may have the ability to absorb selectively and to modify structurally dietary carotenoids, a large number of different carotenoid metabolites may be awaiting detection. Improved analytical methods for the detection and structural elucidation of such carotenoid metabolites on the microgram scale are imperative. Improved HPLC instruments with diode 
array detectors and modern data equipment facilitate quantitative analyses of micro samples including determination of visible absorption spectra of components present in quantities < 1\% of the total carotenoid. Authentic reference compounds are essential. Preparative HPLC is now routinely used for purification prior to ${ }_{\mathrm{H}}$ NMR examination (ref. 20) and such preparative procedures have been described (refs. 70,71). Complete references to the rumerous pubilcations on analytical HPLC of carotenoids which have appeared recently are not included here (cfr. ref. 72). Supercritical fluid chromatography coupled with mass spectroscopy is a promising new tool (ref. 73), and droplet counter-current separation a potential method (ref. 74 ).

\section{Aromatic carotenoids}

The aromatization process for carotenoids is generally associated with bacteria and sponges. Details on the total synthesis of trikentriorhodin ( 27 , scheme 9$)$ have now been reported (ref. 75). The $\mathrm{CD}$ properties of the synthetic and the natural sponge compound are consistent with the $(3 \underline{S}, 5 \underline{R})$-configuration $(27)$. The structure of the aromatic metabolite 28 from a sponge has been confirmed by partial synthesis of a model carotenoid with the 3,4-dehydro-y- end-group from lutein dimesylate by elimination (ref. 76), Scheme 9. Another new aryl carotenoid, 7,8-didehydroaptopurpurin (29) of sponge origin has an acetylenic, methoxylated end group (ref. 77), thereby further extending the occurrence of methoxylated carotenoids outside the phototrophic bacteria. A new aryl carotenoid 30 with a benzylic hydroxy function constitutes, together with astaxanthin, the prosthetic group of the blue carotenoprotein linckiacyanin from starfish (ref. 78).

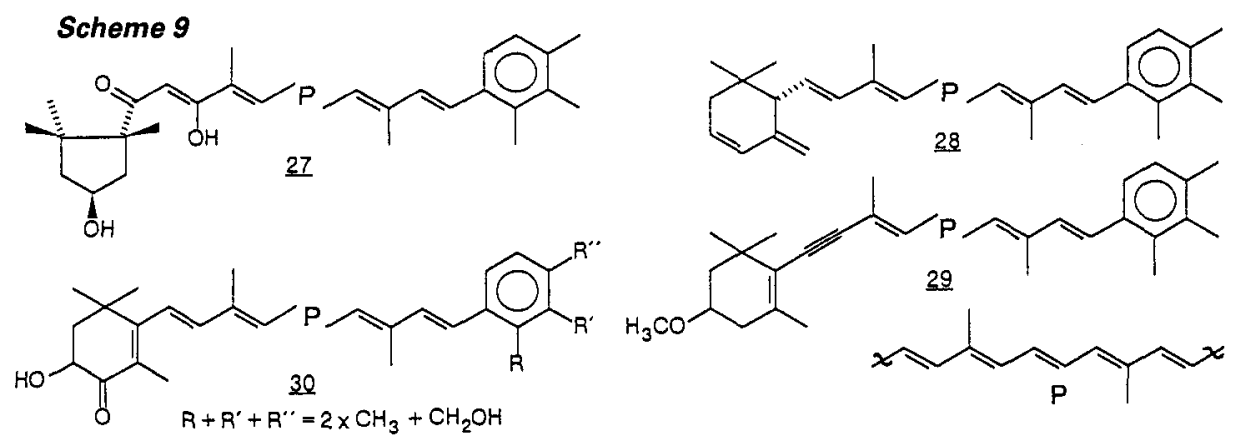

\section{Acetylenic carotenoids}

It is now established that acetylenic carotenoids encountered in marine animals may i) represent dietary, microalgal carotenoids or ii)be formed metabolically from dietary allenic carotenoids (refs. 2,79).

Details of the previous structure elucidation of mytiloxanthin, with proposed $3 \underline{R}, 3^{\prime} \underline{\underline{S}}, 5$ ' $\underline{R}$ chirality (31, scheme 10), and the total synthesis of its thermodynamically more stable 9-cis isomer have now been published (ref. 80 ). The CD properties are reported and discussed (ref, 81).

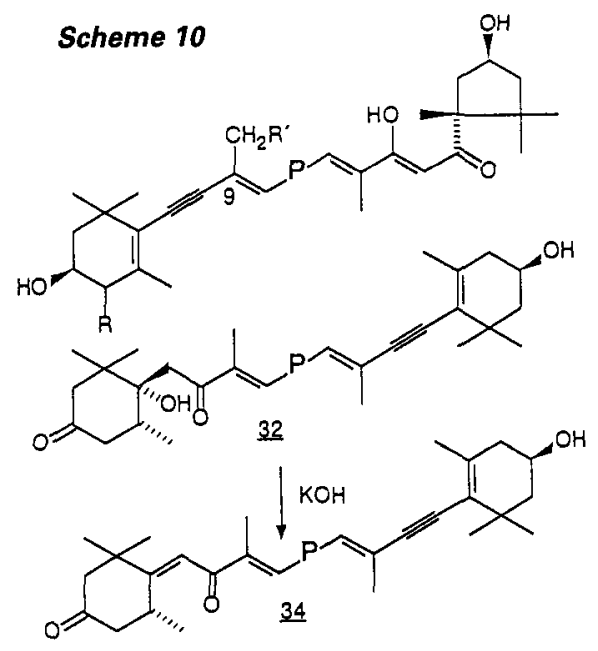

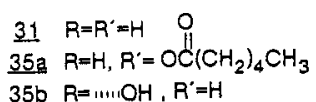<smiles>CCC(=O)C1C(C)CC(=O)CC1(C)O</smiles><smiles>C=CC=C(C)C=CC=CC=C(C)C=CC=CC(C)=CPC=C(C)C#CC1=C(C)CC(O)CC1(C)C</smiles>

Details of the original study of isomytiloxanthin ( $\underline{32}$ ) have also been reported (ref. 82), together with the total synthesis of an MMR model (33), which supports the relative stereochemistry that was assigned. More recent results on isomytiloxanthin (32) include 400 MHz ${ }_{\mathrm{H}}$ NMR spectra, and further characterization of anhydro-isonytiloxanthin (34). The 
latter product is obtained by alkali treatment of isomytiloxanthin (32), which does not result in retro-aldol cleavage. Further acetylenic carotenoid metabolites described from Mytilus edulis are 19'-hexanoyloxyisomytiloxanthin (35), anhydro-amarouciaxanthin B (36) and the $C_{37}$-skeletal hydrato-pyrrhoxanthinol ( 37 ) with a triol end-group (ref. 81). From starfishes has been reported $(3 \underline{S}, 4 \underline{S}, 3 \prime \underline{S}, 5$ 'R $)-4$-hydroxymytiloxanthin $(\underline{35 b})$ (ref. 83). The relative trans configuration for the diol end group rests on a coupling constant of $7.5 \mathrm{~Hz}$ for the $\mathrm{H}-3$ and $\mathrm{H}-4$ methine protons. The similar cotton effect for $\underline{31}$ and $\underline{35} \mathrm{~b}$ does not prove the chirality of the acetylenic end-group, whose CD contribution is small.

The starfish Asterias rubens are previously assumed to introduce 4,4'-keto groups in alloxanthin $(\underline{18}$, Scheme 6$)$. Possible intermediates are now reportad from Japanese starfishes (ref. 83 ). These are $\left(3 \underline{S}, 4 \underline{S}, 3^{\prime} \underline{S}, 4^{\prime} \underline{S}\right)-4,4^{\prime}$-dihydroxyalloxanthin (38, Scheme 11), and $\left(3 \underline{S}, 3^{\prime} \underline{S}, 4^{\prime} \underline{S}\right)-4-k e t o-4 '$-hydroxyalloxanthin (39). Also reported were the corresponding derivatives of diatoxanthin ( 40$)$, namely the cis tetrol $\underline{41}$ and the $\alpha-k e t o l \underline{42}$. valid $1_{H} N M R$ and $C D$ arguments were used for these assignments.

\section{Scheme 11}

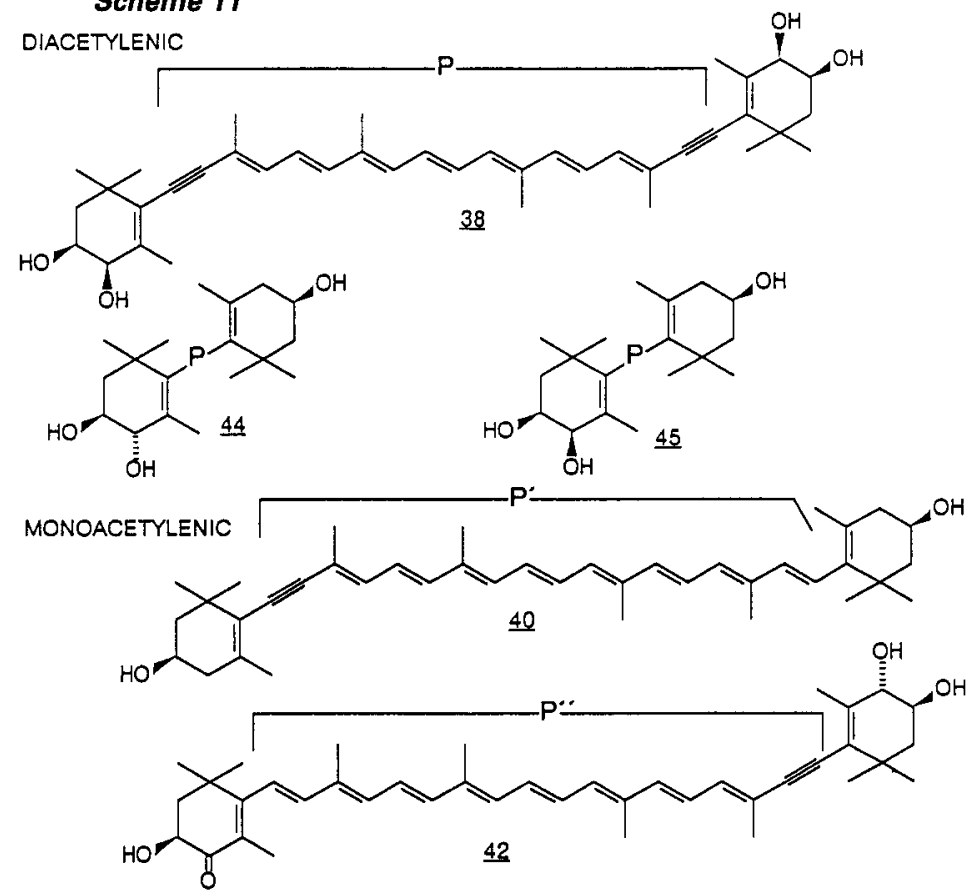<smiles>CC1=C(PC2C(C)=C(PC3=C(C)C(C)(C)C[C@H](O)C3=O)C(C)=C(PC3=C(C)C(C)(C)C[C@H](O)C3=O)C2(C)C)C(C)(C)C[C@H](O)C1=O</smiles>

Three new acetylenic triols of related type have been reported from the Japanese sea mussel Mytilus coruscus, namely pectenol $B(\underline{43}),\left(3 \underline{S}, 4 \underline{R}, 3^{\prime} \underline{R}\right)-4$-hydroxyalloxanthin ( $\left.\underline{4} 4\right)$ and its $C-4$ epimer 45 (ref. 84), see scheme 11. The latter showed a coupling constant of $3.5 \mathrm{~Hz}$ for the $\mathrm{H}-3$ and $\mathrm{H}-4$ methine protons. Again, closely similar $\mathrm{CD}$ spectra were reported for alloxanthin (18) and the two $c-4$ epimers $\underline{44}$ and $\underline{45}$, in agreement with the stereochemical assignment. It is established that $c-4$ substituents have only minor influence on the cotton effect of chiral $\beta$-rings.

It is interesting that a recent report on the crab paralithodes brevipes (ref. 85 ) confirms the earlier findings that diacetylenic astaxanthin (46, asterinic acid, scheme 11), is optically pure $\left(3 \underline{S}, 3^{\prime} \underline{\underline{S}}\right)$, compatible with its metabolic formation from $(3 \underline{R}, 3$ ' $)$-alloxanthin $(\underline{37})$.

Non-acetylenic 4,(4')-ketocarotenoids and their presumed metabolites

The natural occurrence of enantiomeric and meso astaxanthin ( $\underline{46} \underline{a}, \underline{b}, \underline{c}$, Scheme 12) in marine animals has been further illustrated for zooplankton (ref. 86), Penaeidae (shrimps), (ref. 87), crabs (ref, 85) and cephalopoda (ref. 88).

Detailed stereochemical studies have been performed on the metabolite idoxanthin (47), formed in salmon from astaxanthin $(\underline{46} \underline{a}, \underline{b}, \underline{c})$. All the 8 optical isomers have been prepared by synthesis and separated by HPLC as tricarbamates (ref. 89). The metabolic results are discussed elsewhere (ref. 90).

The new $\mathrm{C}_{37}$ apo-carotenal geliodesxanthin (48, Scheme 12), which has one astaxanthin endgroup, has been isolated (ref. 91).

of great structural interest are the yellow carotenoids, representing enolized $\alpha$-iiketones, that have been reported from members of the Penaeidae as esters (ref. 87), namely 49 a $, \underline{b}, \underline{c}$. The relative stereochemistry of the diol end group has been assigned by $1_{\mathrm{H}}$ NMR. Also isolated were the tetrols $\underline{50}$ a, $\underline{b}$. A mechanism for the racemization of astaxanthin $(\underline{46} \underline{a}, \underline{b}, \underline{c})$ in vivo based on these intermediates, is discussed elsewhere (refs. $87,90)$. 


\section{Scheme 12}<smiles>CC1=C(PC2=C(C)C(PC3=C(C)C(O)C(O)CC3(C)C)=C(PC3=C(C)C(O)C(O)CC3(C)C)C(C)(C)C2(C)C)C(C)(C)C[C@H](O)C1=O</smiles><smiles>CC1=C(PC2=C(C)C(=O)[C@@H](O)CC2(C)C)C(C)(C)C[C@H](O)C1=O</smiles><smiles>CC1=C(PC2=C(C)C(=O)[C@@H](O)CC2(C)C)C(C)(C)C[C@H](O)C1=O</smiles><smiles>CC(/C=C/C=C(C)/C=C/C=C(C)/C=C/C=C(C)/C=C/C=C(C)/C=C/C=C/C=O)=C(C)C1=C(C)C(=O)[C@@H](O)CC1(C)C</smiles><smiles>CC1=C(O)C(=O)CC(C)(C)C1PC1[C@H](C)[C@@H](O)[C@@H](O)CC1(C)C</smiles><smiles>[C+]#CPC1=C(C)[C@@H](O)[C@H](O)CC1(C)C</smiles>

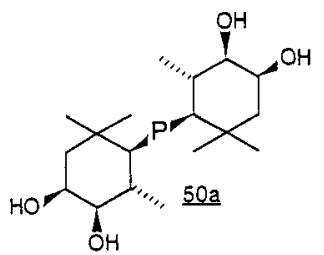<smiles>C[C@H]1[C@H](PC2(C)[C@H](C)[C@@H](O)[C@H](O)CC2(C)C)C(C)(C)C[C@H](O)[C@@H]1O</smiles><smiles>C=CC=CC=CC(C)=CC=CC=C(C)C=CC=C(C)C=CC</smiles>

From chitons have been reported two new carotenoid triols including $(3 \underline{S}, 4 \underline{R}, 3$ ' $\underline{R})-\beta, \beta-$ carotene-3,4,3'-triol (1ㅡ, scheme 13) (ref. 92) with the expected ${ }^{1} \mathrm{H}$ NMR and CD properties.

Echinenone (52a) is metabolically reduced to the 4-01 in various systems. Separation of the $4 \underline{R}(\underline{53 a})$ and $4 \underline{S}(\underline{5 b})$ enantiomers as benzoates has been achieved by chiral HPLC (ref. 93). The method is also applicable to the resolution of $\beta, \beta$-caroten-2-ols.

New 5,6-dihydrocarotenoids have been reported from spindle shells (ref. 94), namely 5,6 -dihydro- $\beta, \beta$-caroten-4-ol $(\underline{54})$ and 5,6-dihydro- $\beta, \beta$-caroten-4-one $(\underline{55})$ of undetermined chirality. Structural studies on the microgram scale included ${ }^{1}$ NMR of $\underline{54}$.

\section{Scheme 13}<smiles>CC1=C(PC2CCCCC2)C(C)(C)C[C@H](O)C1</smiles><smiles>CC1=C(PC2C(C)C(O)CCC2(C)C)C(C)(C)CCC1</smiles><smiles>CCCCCCCC1=C(PC2=C(C)C(=O)CC(C)(C)C2(C)C)C(C)(C)CCC1</smiles><smiles>CC1=C(PC2C(C)C(O)CCC2(C)C)C(C)(C)CCC1=O</smiles><smiles>CC1=C(P)C(C)(C)CCC1=O</smiles><smiles>CC1=C(PC2=C(C)[C@@H](O)CCC2(C)C)C(C)(C)CCC1</smiles><smiles>CC1=C(PC2=C(C)[C@@H](O)CCC2(C)C)C(C)(C)CCC1</smiles><smiles>C=CC=CC(C)=CC=CC=C(C)C=CC=CC(C)=CC=C</smiles>

Astaxanthin $(\underline{46} \underline{a}, \underline{b}, \underline{c})$ is an important feed ingredient in aquaculture. Interest has been centered around the production of secondary keto-carotenoids by green algae as an alternative source of astaxanthin (ref. 95). The synthesis of secondary carotenoids by green algae under high light lilumination also results in cis-isomers, e.g. of $\beta, \beta-$ carotene, canthaxanthin $(\underline{52 b})$ and astaxanthin ( $\underline{46})$. The recent NMR characterizations of Cis isomers of $B, B$-carotene (ref. 96) and canthaxanthin (ref. 97) are useful for diagnostic purposes.

\section{$\epsilon-$ Ring derivatives}

Derivatives of $B, \epsilon$-carotene, exemplified by $\left(3 R, 3^{\prime} R, 6^{\prime} R\right)-$ lutein $(56)$, and of $\epsilon, \epsilon$-carotene, such as the tunaxanthins, including tunaxanthin $A$ (57, Scheme 14), are encountered in marine animals. Details have now been published of the partial syntheses of the three other G'R diastereomers of lutein $(\underline{56})$ by application of the Mitsunobo reaction (ref. 98). The observed cotton effects of eight lutein diastereomers have been rationalized by means of the additivity hypothesis (ref. 98). Semi-rational designations for these lutein isomers were also suggested (ref. 98). This system differs from the non-systematic A-H designations for the luteins (ref. 98) and the non-systematic A-J tunaxanthin designations for the ten $\epsilon, \epsilon$-carotene-3,3'-diol diastereomers, including 57 (ref. 99). 


\section{Scheme 14}<smiles>CC1=C[C@H](O)CC(C)(C)C1PC1=C(C)C[C@@H](O)CC1(C)C</smiles><smiles>[Z18]CC1=C[C@@H](O)CC(C)(C)[C@H]1PC1C(C)=C[C@H](O)CC1(C)C</smiles><smiles>CC1=C[C@@H](O)CC(C)(C)C1PC1C(C)[C@H](O)[C@H](O)CC1(C)C</smiles><smiles>CC1=C[C@@H](O)CC(C)(C)C1PC1=C(C)[C@@H](O)[C@H](O)CC1(C)C</smiles><smiles>CC1=CC(=O)CC(C)(C)C1P[C@H]1C(C)=CC(=O)CC1(C)C</smiles><smiles>CC1=CC(O)CC(C)(C)C1P[C@H]1C(C)=CC(=O)CC1(C)C</smiles><smiles>CC1=CC(=O)CC(C)(C)C1P[C@H]1C(C)=C[C@@H](O)CC1(C)C</smiles><smiles>C/C=C(/C)[P](=P)C1C(C)=CC(=O)CC1(C)C</smiles>
, $\mathrm{OH}$<smiles>[X]C=CC(C)=CC=CC(C)=CC=CC=C(C)C=CC=C(C)C=C</smiles>

Papilioerythrinone from the crab paralithodes brevipes has now been reported to have the $\left(3 \underline{S}, 6^{\prime} R\right)$-configuration 58 (ref. 85), Scheme 15. The optical purity of this $\alpha$-ketol is surprising since 58 occurs together with racemized astaxanthin $(\underline{46}, \underline{a}, \underline{b}, \underline{c})$. Reduction of papilioerythrinone ( $58,0.6 \mathrm{mg}$ ) with $\mathrm{NaBH}_{4}$ provided four triols which were separated by HPLC on a Sumipax column. The VIS, $1_{\mathrm{H}} \mathrm{NMR}(300 \mathrm{MHz})$ and $\mathrm{CD}$ spectra were obtained for each isomer and compared with those of the corresponding triols obtained from fritschiellaxanthin (모) and doradexanthin (으), see scheme 15.

From spindle shells was also isolated 30 micrograms of a triol that was assigned the constitution 5,6-dihydro- $\beta, \epsilon$-carotene-3,4,31-triol with tentative chirality (61) (ref. 94), Scheme 14. It is amazing that preparation of a triacetate, a trimethylsilyl ether, an acetonide and an allylic hydroxyl test could be effected with this quantity, and a mass spectrum obtained.

\section{Scheme 15}

cited from ref. 85

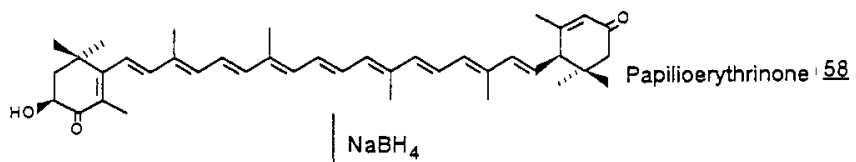

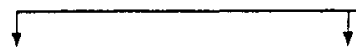

Triol (1)

Triol (2)

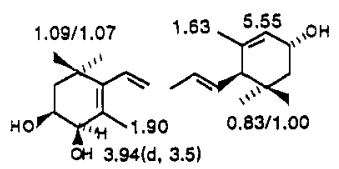

Triol (1')

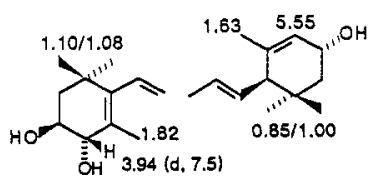

Triol (2')<smiles>CC1=C[C@H](O)CC(C)(C)[C@H]1/C=C/C(C)=C/C=C/C(C)=C/C=C/C=C(C)/C=C/C=C(C)/C=C/[C@@]1(C)C[C@@H](O)C(=O)C(C)=C1C</smiles>

Fritschiellaxanthin

$\underline{59}$

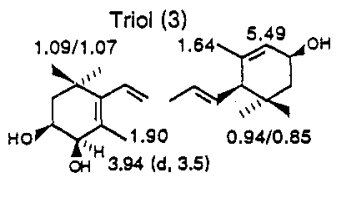

Triol (3')
Triol (4)

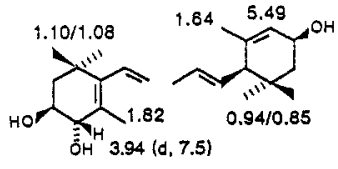

Triol (4')<smiles>CC1=C[C@H](O)CC(C)(C)[C@H]1/C=C/C(C)=C/C=C/C(C)=C/C=C/C=C(C)/C=C/C=C(C)/C=C/C=C1C(C)=C(C)C(=O)[C@H](O)CC1(C)C</smiles>

$\underline{60}$

$A$ new $\beta, \epsilon$-carotene-derived triol has also been reported from chitons (ref. 92 ) and assigned the structure $\left(3 \underline{S}, 4 \underline{R}, 3^{\prime} \underline{R}, 6^{\prime} \underline{R}\right)-\beta, \epsilon-$ carotene-3,4,3'-triol (62, scheme 14). Chemical derivatization and partial synthesis by $\mathrm{NaBH}_{4}$-reduction from fritschiellaxanthin (59, Scheme 15) confirmed this assignment. Amongst the twentyfive identified carotenoids from chitons were the $\epsilon, \epsilon$-carotene derivatives shown in Scheme 14 , including the $\left(6 \underline{S}, 6^{\prime} \underline{S}\right)$-dione 63 , its enantiomer ent- $\underline{63}$ and the meso form, the $\left(3 \underline{S}, 6 \underline{S}, 6^{\prime} \underline{S}\right)-3-h y d r o x y-\epsilon, \epsilon-$ caroten-3'-one $(\underline{64})$ and its enantiomer ent- $\underline{64}$, and tunaxanthin $A(\underline{57})$. The diones 63 , ent- $\underline{63}$ and the corresponding meso form, and the ketones $\underline{64}$ and ent $-\underline{64}$, as well as the ketones $\underline{65}\left(6 \underline{\underline{S}}, 3^{\prime} \underline{R}, \sigma^{\prime} \underline{S}\right)$ and $\underline{66}$ $\left(6 \underline{R}, 3^{\prime} \underline{R}, 6^{\prime} \underline{S}\right.$ ) had previously been reported from tuna (Thunnus obesus) (ref. 100). The configurational mixtures encountered in the $\epsilon, \epsilon$-series are indeed amazing. This development was not foreseen twenty years ago when it was assumed that each carotenoid constitution occurred with one preferred configuration. 


\section{APPLIED ASPECTS}

Isolation in the pure state, identification and structural elucidation of marine carotenoids, usually on the microgram/milligram scale, represent a challenge in themselves. Improved methodology, particularly in HPLC and high-field ${ }^{1} \mathrm{H}$ NM, permits advances and has steadily reduced the required sample sizes.

However, the stronger motivation for a natural product chemist comes from the interdisiplinary problems, to the solution of which such structural studies may contribute.

Concerning marine carotenoids their use in chemosystematics for microalgae (ref. 6) is generally accepted. The application of carotenoids to systemtatic studies in sponges has been attempted (ref. 100), with less success.

Currently detailed HPLC analysis of chlorophylls and carotenoids in sea water is being developed as a routine analysis in oceanography for recording algal blooms (refs. 102, 103). The results can only be interpreted with a detailed knowledge of the structures and distribution of the photosynthetic pigments in each algal class.

Carotenoids are also useful indicators for geochemical events. Studies of carotenoids and their derivatives in sediment cores may reveal previous phytoplanctic (refs. 58,103) or bacterial (ref. 25) blooms.

In recent years carotenoids have proved to be useful markers in studies of marine food chains. Studies on Mytilus edulis (ref. 79) and on fish feeding with individual carotenoids have $\underline{e} . g$ been published during the period covered here.

Functional aspects of marine carotenoids as vitamin A precursors, participation in photosynthesis as auxiliary light absorbers and in phototaxis, as protectors against photodynamic damage, possible participation in oxygen transport, alarm or protective colours etc. are known and are being pursued. Hitherto unknown functions are receiving current attention. Why are acetylenic carotenoids accumulated in edible mussels and starfishes? A protective function against predators appears likely in view of similar known functions for other polyacetylenic compounds (ref. 104). In the near future, acetylenic and allenic carotenoids will be subjected to various biological activity assays. Preliminary positive results have already appeared (ref. 105).

As to industrial aspects of marine carotenoids the developments leading to the successful application of synthetic nature-identical astaxanthin as a feed ingredient in aquaculture for salmon production have been reviewed (ref. 106).

The necessity of rigorous structure determination of the carotenoids that are encountered in modern studies on the biosynthesis and metabolism of marine carotenoids at the molecular level is obvious. General biosynthesis (ref. 107), metabolism of marine carotenoids (ref. 90), carotenoproteins (ref. 108) and photosynthetically active protein complexes are covered by others.

Moreover, the more complex marine carotenoids with several functional groups and chiral centers present particular challenges for the synthetic chemist. Thus the industrial synthesis of astaxanthin $(\underline{46} \underline{a}, \underline{b}, \underline{c})$ and the total synthesis of the diepoxide violaxanthin (23) with six chiral centres (ref. 67) and of the $C_{37}$-skeletal butenolide peridinin (B) with correct relative configuration (ref. 60) have been achieved during the period covered. Fucoxanthin (a) and $P 457(\underline{16})$ are no doubt attractive goals for the future.

\section{Acknowledgement}

Much of the literature covered was collected by Dr. H. -R. Sliwka for general literature seminars in our research group.

\section{REFERENCES}

1. T. Bjørnland, in Carotenoids : Chemistry and Biology, (N.I. Krinsky, M.M. MathewsRoth and R.F. Taylor, eds.), Plenum, New York. pp. 21-38.

2. T. Matsuno, in Carotenoids : Chemistry and Biology, (N.I. Krinsky, M.M. Mathews-Roth and R.F. Taylor, eds.) Plenum, New York. pp. 59-74.

3. G. Britton, Nat, Prod. Rep, 6 , 359-392 (1989).

4. T. Matsuno and S. Hirao, in Marine Biogenic Lipids, Fats and Oils (R.G. Ackmann, ed.), Vol. 1, CRC Press, Florida, pp. 251-388.

5. S. Liaaen-Jensen, Pure Appl, Chem. 61, 369-372 (1989).

6. T. Bjornland and.S. Liaaen-Jensen, in The Chromophyte Algae, Problems and Perspectives (B.S.C. Leadbeater, J.C. Green and W.I. Diver, eds.) Clarendon, Oxford, 1989, pp. $37-61$. 
7. S. Liaaen-Jensen, in studies in Natural Products Chemistry, (T.I. Atta-ur-Rahman, ed.) Vol. 6, Stereoselective Synthesis (Part D), Elsevier, Amsterdam, pp. 133-170.

8. S. Liaaen-Jensen, Noveau Journal de Chemie. In press.

9. H. Pfander, Key to Carotenolds, 2nd Ed., Birkhauser, Basel, 1987.

10. J.-C. Bertrand and H. Larsen, in Micro-organismes dans les ecosystemes oceaniques, (M. Bianchi, ed.) Masson, Paris, 1989, pp. 3-25.

11. S. Takaishi, K. Shimada and J. Ishidsu, Arch, Mikrobiol. 153, 118-122 (1990).

12. S. Takaishi, K. Shimada and J. Ishidsu, Phytochemistry. 27, 3605-3608 (1988).

13. G. Englert, E. Glinz and S. Liaaen-Jensen, J, Magn, Resonance 26, 55-63 (1988).

14. G. Englert, E. Glinz and S, Liaaen-Jensen, Unpublished results.

15. S. Ichiyami, K. Shimokata and M. Bakamara, Microbiol, Immunol. 32, 473-479 (1988).

16. S. Ichiyami, K. Shimokata, M. Tsukamara, Mikrobiol. Immunol, 33, 503-508 (1989).

17. B. Berland, T.Le Campion and M.H. Neves, Bot. Mar. 32, 317-29 (1989).

18. H.J. Nelis and A.P. de Leenheer, Appl. Environ, Microbiol. 55, 3065-3071 (1989).

19. G. Englert, Pure Appl, Chem. This volume.

20. T. Aakermahn, G. Englert, K. Schiedt, E. Glinz, R.R.I. Guillard and S. Liaaen-Jensen, Abstr, 9th Int, IUPAC Carotenoid Symp. p.80, Kyoto, 1990.

21. T. Aakermann, B.E. Christensen, P. Foss, M. Rønnekleiv, O. Skulberg, G. Eidsá and $S$. Liaaen-Jensen, Abstr, 9th Int, IUPAC Carotenoid Symp. p.81, Kyoto, 1990.

22. R. Riesen, H. Pfander and $\mathrm{K}$ Schiedt, Abstr, 9 th Int, IUPAC Carotenoid Symp. München, P4O (1984).

23. M. Gerspacher and H. Pfander, Helv, Chim, Acta $72,151-157$ (1989).

24. J.P. Ferezou and M. Julia. Tetrahedron 46, 475-486 (1990).

25. R. Summons, Geochem, Acta 51, 551-557 (1987).

26. J.L. Stauber and S.W. Jeffrey, J. Phycol. 24, 158-172 (1988).

27. F. Pennington, R.R.L. Guillard and S. Liaaen-Jensen, Biochem, Syst, Ecol. 16, 589-592 (1988).

28. B. Creczuga and F.J. Taylor, Biochem. Syst, Ecol. 15, 5-8 (1987).

29. J.A. Haugan and S. Liaaen-Jensen, Abstr, 9th Int, IUPAC Carotenoid Symp. p.79, Kyoto, 1990.

30. C. Paradossi, G. Lotti and F. Marchini, Agrochimia 32, 354-359 (1989).

31. P. Foss, R.A. Lewin and S. Liaaen-Jensen, Phycologia 26, 142-144 (1987).

32. T. Bjørnland, C. Pereira, S. Liaaen-Jensen, R.R.L. Guillard and R.R. Bidigare, Abstr. 8th Int. Carotenoid Symp. Boston, 1987, P39; T. Bjørnland, R.R.L. Guillard and S. Liaaen-Jensen, To be published.

33. C.E.Hooks, R.R.Bidigare, M.D.Keller and R.R.L.Guillard, J, Mycol. 24, 571-580 (1988).

34. T. Bjornland, A. Fiksdahl, T. Skjetne, J. Krane and S. Liaaen-Jensen, Abstr. Internat, Carotenoid Symp., Boston 1987, P2.

35. K. Tangen, H. Grasdalen, L. Jørgensen, T. Bjørnland, A. Fiksdahl and S. Liaaen-Jensen, Abstr. Int. Symp. Chromophyte Algae, Plymouth, 1988.

36. B. Bjerkeng, M. Vernet, M. Nielsen and S. Liaaen-Jensen, Biochem. Syst, Ecol. Submitted.

37. B. Bjerkeng, J.A. Haugan and $S$. Liaaen-Jensen, Biological Oceanography. In press.

38. T. Bjørnland, F. Pennington, F.T. Haxo and S. Liaaen-Jensen, Abstr. 7th Internat. IUPAC Carotenoid Symp. P26, Munchen, 1984; To be published.

39. T. Bjørnland, A. Fiksdahl, F.T. Haxo and S. Liaaen-Jensen, Abstr, 8th Internat. Carotenoid Symp. P1, Boston, 1987.

40. A. Fiksdahl and S. Liaaen-Jensen, Phytochemistry 27, 1447-1450 (1988).

41. T. Bjørnland, R.R.L. Guillard and S. Liaaen-Jensen, Biochem. Syst. Ecol. 16, 445-452 (1988).

42. M. Vesk and S.W. Jeffrey, J. Phycol. 23, 322-336 (1987).

43. T. B jornland, J. Throndsen and S. Liaaen-Jensen, Phytochemistry 28, 3347-3353 (1989).

44. K. Kohata and M. Watanabe, J, Phycol. 24, 58-66 (1988).

45. S.W. Wright and S.W. Jeffrey, Mar. Ecol, Progr, Ser. 38, 259-266 (1987).

46. J.A. Haugan and S. Liaaen-Jensen, Phytochemistry 28, 2797-2798 (1989).

47. T. Aakermann, J. Krane and S. Liaaen-Jensen, Acta Chem, Scand. To be published.

48. G. Englert, T. Bjornland and S. Liaaen-Jensen, Magnetic Reson, Chem. In press.

49. J.A. Haugan, G. Englert, E. Glinz and S. Liaaen-Jensen, Abstr. 9th Int. IUPAC Carotenoid Symp. p.78, Kyoto, 1990.

50. K. Bernhard, G.P. Moss, G. Toth and B.C.I. Weedon, Tetrahedron Letters, 1974, 3899-3902.

51. T. Bjornland, T. Skjetne and S. Liaaen-Jensen, Abstr, 8th Internat, Carotenoid Symp. P3, Boston, 1987.

52. T. Bjornland, G. Englert, K. Bernhard and S. Liaaen-Jensen, Tetrahedron Letters 30 , 2577-2580 (1989).

53. V. Sturzenegger, R. Buchecker and G. Wagniere, Helv. Chim, Acta 63, 1074-1092 (1980).

54. J. L. Ballard, L.A. Glasgow, L.C. Hoskins and T. Krohe, Spectrochim. Acta 45A, 1235-8 (1989).

55. J.A. Haugan, G. Englert and S. Liaaen-Jensen, Abstr, gth Int. IUPAC Carotenoid Symp. p.112, Kyoto, 1990.

56. J.A. Haugan and S. Liaaen-Jensen, Abstr, 9th Int. IUPAC Carotenoid Symp. p.113, Kyoto, 1990.

57. D.J. Repeta and N.M. Frew, Org. Geochem. 12, 469-477 (1989).

58. D.J. Repeta, Geochim. Cosmochim, Acta 53, 699-707 (1989). 
59. T. Skjetne, T. Bjørnland and S. Liaaen-Jensen, Abstr, 7 th Int, IUPAC Carotenoid Symp. P36, Munchen, 1984; To be published.

60. M. Ito, Y. Hirata, Y. Shibata and K. Tsukida, J. Chem. Soc. Perkin Trans. I, $197-199$ (1990).

61. M. Ito, Pure Appl, Chem. This volume.

62. T. Bjørnland, T. Skjetne and S. Liaaen-Jensen, Abstr, 8th Internat, Carotenoid Symp. P3, Boston, 1987; To be published.

63. T. Bjornland, A. Fiksdahl, T. Skjetne and S. Liaaen-Jensen, In preparation.

64. T. W. Goodwin, The Biochemistry of the Carotenoids, Vol. 1. Plants, 2nd Ed., Chapman \& Hall, London, 1980.

65. M. Acemoglu, P. Uebelhart, M. Rey and C.H. Eugster, Helv.Chim,Acta 71, 931-956 (1988).

66. H. Pfander, Pure Appl, Chem. This volume.

67. M. Acemoglu and C.H. Eugster, Helv. Chim, Acta 67, 184-190 (1984).

68. L.B. de Almeida, M.de Vuono Camargo Penteado, G. Britton, P. Uebelhart, M. Acemogiu and C.H. Eugster, HelV, Chim, Acta 71, 31-32 (1988).

69. H.Y. Yamamoto, C.O. Chichester and T.O.M. Nakayama, Anal. Chem. 33, 1792 (1961).

70. M. Isaksen and G.W. Francis, Chromatographia 27, $325-327$ (1989).

71. S. Scalia and G.W. Francis, Chromatographia 28, 129-132 (1989).

72. H. Khachik, Pure Appl. Chem. This volume.

73. J.R. Chapman, Rapid Commun. Mass Spectrom. 2 6 6-7 (1989).

74. G.W. Francis and $M$. Isaksen, Chromatographia 27, 549-51 (1989).

75. A.K. Chopra, G.P. Moss and B.C.L. Weedon, J. Chem, Soc. Perkin Trans. I, $1371-82$ (1989).

76. H. -R. Sliwka, O.W. Nøkleby and S. Liaaen-Jensen, Acta Chem. Scand. B41, 245-252 $(1987)$.

77. Y. Tanaka and T. Inoue, Nippon Suisan Gakkaishi 54, 155 (1988).

78. P.F. Zagalsky, F.T. Haxo, S. Hertzberg and S. Liaaen-Jensen, Comp. Biochem, Physiol. 93B, 339-353 (1989).

79. V. Partali, K. Tangen and S. Liaaen-Jensen, Comp.Biochem. Physiol. 92B, 239-246 (1989).

80. A.K. Chopra, A. Khare G.P. Moss and B.C.I. Weedon, I, Chem, Soc. Perkin Trans. I, 1383-1388 (1988).

81. S. Hertzberg, V. Partali and S. Liaaen-Jensen, Acta Chem, Scand. B42, 495-503 (1988).

82. A. Khare, G.P. Moss and B.C.L. Weedon, J, Chem, Soc, Perkin Trans.I, 1389-1395 $(1988)$.

83. T. Maoka, M. Tsushima and T. Matsuno, Comp. Biochem. Physiol. 93B, 929-934 (1989).

84. T. Maoka and T. Matsuno, Nippon Suisan Gakkaishi 54, 1443-1447 (1988).

85. T. Matsuno and T. Maoka, Nippon Suisan Gakkaishi 54, 1437-1442 (1988).

86. P. Foss, B. Renstrøm and S. Liaaen-Jensen, Comp. Biochem. Physiol. 86B, 313-314 (1987).

87. K. Schiedt, Absorption, Retention and Metabolic Transformations of Carotenoids in Chicken, salmon and Crustaceae. Dr.techn. Thesis, Univ. Trondheim-NTH, 1987.

88. T. Maoka, S. Yokoi and T. Matsuno, Comp. Biochem. Physiol. 92B, 247-250 (1989).

89. K. Schiedt, H. Mayer, M. Vecchi, E. Glinz and T. Storebakken, Helv. Chim. Acta 71 , 881-895 (1988).

90. K. Schiedt, S. Bischof and E. Glinz, Pure Appl. Chem. This volume.

91. $Y$. Tanaka and $T$. Inoue, Nippon Suisan Gakkaishi 53, 1271-1273 (1987).

92. M. Tsushima, T. Maoka and T. Matsuno, Comp. Biochem. Fhysiol. 93B, 665-671 (1989).

93. T. Maoka and T. Matsuno, J. Chromatogr. 482, 189-195 (1989).

94. T. Matsuno and M. Tsushima, Comp. Biochem. Physiol. 92B, 189-193 (1989).

95. M. Grung, B. Bjerkeng, M. Borowitzka, 0 . Skulberg and $S$. Liaaen-Jensen, Abstr. 9th Internat. IUPAC Carotenoid Symp. Kyoto, 1990.

96. Y. Koyama, M. Hosomi, H. Hashimoto and T. Shimamura, J. Mol, Struct. 193, 185-201 (1989).

97. H. Hashimoto, Y. Koyama and T. Shimamura, J. Chromatogr. 448, 182-187 (1988).

98. H.-R. Sliwka and S. Liaaen-Jensen, Acta Chem. Scand., B41, 518-522 (1987).

99. Y. Ikuno, M. Shimizu, Y. Koshino, T. Maoka and T. Matsuno, Nippon Suisan Gakkaishi 51, 2033-2035 (1985).

100. Y. Ikuno and T. Matsuno, Nippon Suisan Gakkaishi 53, 1893-1896 (1987).

101. S. Liaaen-Jensen, B. Renstrom, T. Ramdahl, M. Hallenstvet and P.R. Bergquist, Biochem. Syst. ECol. 10, 167-174 (1982).

102. SCOR/UNESCO Determination of Photosynthetic Pigments in Sea Water. In preparation.

103. W.W.C. Gieskes and G.W. Kraay, Deep-Sea Research 36, 1127-1139 (1989).

104. J.B. Harborne, In Phytochemical Methods, a Guide to Modern Techniques of Plant Analysis, Chapman \& Hall, London, 1973, p.154-159.

105. J. Okuzumi, H. Nishino, A. Iwashima and T. Takahashi, Aostr. 3rd Jap. Scient. Meeting Carotenoids, Tokyo, 1989.

106. K. Bernhard, in Carotenoid Chemistry and Biology, (N.I. Krinsky, M.M. Mathews-Roth and R.F. Taylor eds.) Plenum, New York, pp. 337-364.

107. G. Britton, Pure Appl, Chem. This volume.

108. D. Askin and G. Britton, Abstr, 9th Internat. IUPAC Carotenoid Symp. Kyoto, 1990. 